\title{
Age-Related Cochlear Synaptopathy: An Early-Onset Contributor to Auditory Functional Decline
}

\author{
Yevgeniya Sergeyenko, ${ }^{1}$ Kumud Lall, ${ }^{1,3}$ M. Charles Liberman, ${ }^{1,3}$ and Sharon G. Kujawa ${ }^{1,2,3}$ \\ ${ }^{1}$ Eaton-Peabody Laboratories and ${ }^{2}$ Department of Audiology, Massachusetts Eye and Ear Infirmary, Boston, Massachusetts 02114, and ${ }^{3}$ Department of \\ Otology and Laryngology, Harvard Medical School, Boston, Massachusetts 02115
}

Aging listeners experience greater difficulty understanding speech in adverse listening conditions and exhibit degraded temporal resolution, even when audiometric thresholds are normal. When threshold evidence for peripheral involvement is lacking, central and cognitive factors are often cited as underlying performance declines. However, previous work has uncovered widespread loss of cochlear afferent synapses and progressive cochlear nerve degeneration in noise-exposed ears with recovered thresholds and no hair cell loss (Kujawa and Liberman 2009). Here, we characterize age-related cochlear synaptic and neural degeneration in CBA/CaJ mice never exposed to high-level noise. Cochlear hair cell and neuronal function was assessed via distortion product otoacoustic emissions and auditory brainstem responses, respectively. Immunostained cochlear whole mounts and plastic-embedded sections were studied by confocal and conventional light microscopy to quantify hair cells, cochlear neurons, and synaptic structures, i.e., presynaptic ribbons and postsynaptic glutamate receptors. Cochlear synaptic loss progresses from youth (4 weeks) to old age (144 weeks) and is seen throughout the cochlea long before age-related changes in thresholds or hair cell counts. Cochlear nerve loss parallels the synaptic loss, after a delay of several months. Key functional clues to the synaptopathy are available in the neural response; these can be accessed noninvasively, enhancing the possibilities for translation to human clinical characterization.

\section{Introduction}

Auditory function declines with age, with reductions in threshold sensitivity and speech discrimination, particularly in noise, commonly observed (Working Group on Speech Understanding, Committee on Hearing, Bioacoustics, and Biomechanics, 1988; Goŕdon-Salant, 2005). Understanding of the cellular changes that lead to these outcomes remains fragmentary, and clinical assessments provide an incomplete picture of the sites of involvement and the perceptual impacts of auditory aging.

The loss of threshold sensitivity that accompanies auditory aging is primarily peripheral in origin, and often sensory (i.e., related to hair cell damage or loss) in nature. Much experimental effort has focused on correlating such age-related threshold shifts with hair cell loss, and therapeutic interventions have concentrated on improving "audibility" through amplification. However, threshold sensitivity loss is not the only, and arguably not the primary, handicapping dysfunction of auditory aging. Aging listeners also experience greater difficulty in understanding speech in adverse listening environments; for example, in conditions of background noise and high reverberation, and they ex-

\footnotetext{
Received April 29, 2013; revised July 2, 2013; accepted July 12, 2013.

Author contributions: S.G.K. designed research; Y.S., K.L., and S.G.K. performed research; M.C.L. and S.G.K. analyzed data; M.C.L. and S.G.K. wrote the paper.

This work was supported by National Institute on Deafness and other Communication Disorders Grants R01 DC08577 (S.G.K.) and R01 DC00188 (M.C.L.).

The authors declare no competing financial interests.

Correspondence should be addressed to Dr. Sharon G. Kujawa, Eaton-Peabody Laboratory, Massachusetts Eye and Ear Infirmary, 243 Charles Street, Boston, MA 02114-3096. E-mail: sharon_kujawa@meei.harvard.edu.

DOI:10.1523/JNEUROSCI.1783-13.2013

Copyright $\odot 2013$ the authors $\quad 0270-6474 / 13 / 3313686-09 \$ 15.00 / 0$
}

hibit degraded temporal resolution, even when thresholds are well preserved or when audibility is matched to that of younger listeners (Dubno et al., 1984; Goŕdon-Salant and Fitzgibbons, 1993; Snell and Frisina, 2000; Walton, 2010; Ruggles et al., 2012). In the absence of threshold evidence for peripheral involvement, central and cognitive factors are often invoked as contributing to such performance decrements of aging listeners (Frisina and Frisina, 1997; Krull et al., 2013).

Although thresholds and hair cell counts are important metrics in the assessment of sensory dysfunction, they are less informative when the dominant pathology is not sensory in nature. It has been known for decades that loss of auditory nerve fibers, the primary sensory neurons connecting the hair cells to the auditory brainstem, need not affect threshold sensitivity when the degeneration is diffusely distributed along the cochlear spiral (Schuknecht and Woellner, 1953). More recently, thresholds were shown to be insensitive to widespread loss of the inner hair cell (IHC) synapses of these neurons that can occur after noise exposures causing only temporary threshold elevations (Kujawa and Liberman, 2009).

Comparatively little is known about the effects of aging per se on the IHC-afferent synapse, and normal synaptic aging has been largely overlooked as a contributor to auditory functional decline. This synaptic complex is the primary conduit for information flow from the cochlea to the brain; thus, age-related changes would be expected to have significant perceptual consequences.

Here, we focus on cochlear synaptic aging and its functional consequences in $\mathrm{CBA} / \mathrm{CaJ}$ mice never exposed to high levels of sound. In the same ears, we perform conventional assessments of threshold sensitivity and counts of outer and inner hair cells and 

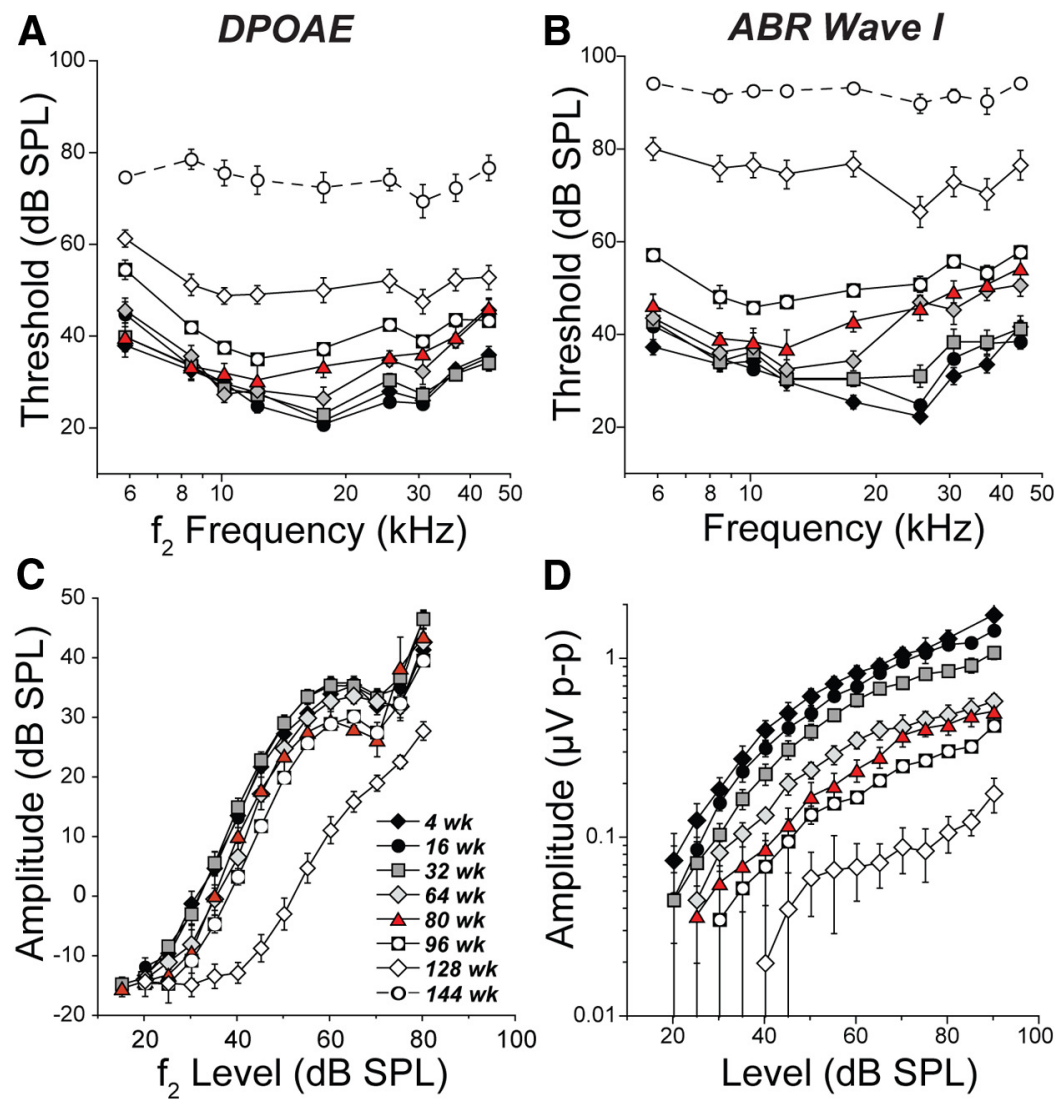

Figure 1. Aging mice show late-onset elevation of cochlear thresholds, preceded by selective decline of neural suprathreshold amplitudes. $\boldsymbol{A}, \boldsymbol{B}$, Mean thresholds ( \pm SEM) for DPOAEs and ABR Wave 1 , as measured at eight ages. The key in $\boldsymbol{C}$ applies to all panels. Actual ages were within $\pm 5 \%$ of the target. When responses were not observed at the highest sound level, threshold was assigned a value $5 \mathrm{~dB}$ greater than the stimulus maximum; this was common only at 144 weeks, where threshold curves are displayed with dashed lines. Group sizes were 4 weeks (12), 16 weeks (20), 32 weeks (12), 64 weeks (16), 80 weeks (10), 96 weeks (20), 128 weeks (20), and 144 weeks (10). C, $\boldsymbol{D}$, Mean amplitude versus level functions ( \pm SEM) at $12 \mathrm{kHz}$ for DPOAEs ( $\boldsymbol{C}$ ) and ABR Wave $1(\boldsymbol{D})$ for the same animals shown in $\boldsymbol{A}$ and $\boldsymbol{B}$ (except for 144 weeks, where waveforms were too small and irregular to reliably parse). In all panels, symbols for 80 week animals are filled with red.

cochlear ganglion cells for comparison. We find significant synaptic losses long before declines in threshold sensitivity or hair cell counts. We show that the extent of synaptopathy can be predicted noninvasively, using auditory brainstem responses that could be optimized for clinical use. Findings provide insights into "normal" peripheral auditory aging and suggest that one need not look beyond the first afferent synapse to find an early, and potentially major, contributor to the performance declines of aging listeners.

\section{Materials and Methods}

Experimental animals and acoustic environment

All mice $(\mathrm{CBA} / \mathrm{CaJ})$ were born and reared in our animal care facility (inbred breeders replaced every five generations to maintain isogeneity with supplier stocks) and held to various ages (4-144 weeks). Since male CBA mice accumulate age-related threshold shift faster than females (Guimaraes et al. 2004; Henry 2004), we used only males to decrease intersubject variability.

The acoustic environment of this facility has been characterized by both spectral analysis and longitudinal noise-level data logging. For the former, a small electret microphone (FG-23329-PO7; Knowles) was placed in an empty mouse cage within an active rack, and the signal was digitized and averaged ( 16 spectra every $10 \mathrm{~s}$ ) for $48 \mathrm{~h}$ over two separate weekdays and two separate weekends. From each mean spectrum, the sound pressure level (SPL) was summed within half-octave bands over the range 1 to $45 \mathrm{kHz}$. Averaged sound levels were greatest $(45-50 \mathrm{~dB})$ in the 1-
$4 \mathrm{kHz}$ span of frequencies, and ranged between 35 and $40 \mathrm{~dB}$ from 5.6 to $45 \mathrm{kHz}$. For the noiselevel data logging, measurements were made for 6 to $24 \mathrm{~h}$ periods and provide A-weighted levels in the frequency range $10 \mathrm{~Hz}$ to $20 \mathrm{kHz}$, which captures the frequency region with highest sound levels. Logged sound levels were between 50 and $60 \mathrm{~dB}$ SPL $>95 \%$ of the time, and $>80 \mathrm{~dB}$ SPL $<1 \%$ of the time.

\section{Physiological tests}

All physiologic tests were conducted in an acoustically and electrically shielded and heated chamber, using a National Instruments PXI-based system and 24-bit input/output boards controlled with custom LabVIEW software. The custom acoustic system comprised two miniature dynamic earphones as sound sources (CDMG15008-03A; CUI) and an electret condenser microphone (FG-23329-PO7; Knowles) coupled to a probe tube to measure sound pressure near the eardrum. Additional details of the stimulus generation and delivery and data acquisition hardware and software can be found at http://www.masseyeandear.org/ research/ent/eaton-peabody/epl-engineeringresources/.

Mice were anesthetized with ketamine (100 $\mathrm{mg} / \mathrm{kg}$, i.p.) and xylazine $(10 \mathrm{mg} / \mathrm{kg}$, i.p.). The condition of the external and middle ears was evaluated under microscopic observation before physiologic testing. Animals with evidence of middle-ear pathology or obstructive cerumen were excluded from the study. During testing, body temperature was maintained at $37^{\circ} \mathrm{C}$ by heating the air in the experimental chamber. All animal procedures were approved by the Institutional Animal Care and Use Committee of the Massachusetts Eye and Ear Infirmary and are consistent with NIH guidelines.

Auditory brainstem responses (ABRs) and distortion product otoacoustic emissions (DPOAEs) were measured from all animals. ABRs were elicited by tone burst stimuli ( $0.5 \mathrm{~ms}$ rise-fall, 30 per second, polarity alternating) delivered at log-spaced frequencies from 5.6 to $45.2 \mathrm{kHz}$. Stimulus SPL was incremented in $5 \mathrm{~dB}$ steps from below threshold to $90 \mathrm{~dB}$ SPL. Responses were amplified $(10,000 \times)$, filtered $(0.3-3 \mathrm{kHz}$ passband), averaged (up to 1024 samples at each frequency level combination), and detected via needle electrodes at the vertex and ventrolateral to the pinna with a ground reference near the tail. ABR Wave 1 thresholds, defined as the lowest stimulus level (in decibels of SPL) at which a repeatable Wave 1 could be identified in the response waveform, were identified by visual inspection of stacked waveforms. Amplitudes of Waves 1 and 5 were measured (peak to following trough) by offline analysis of stored waveforms.

DPOAEs corresponding to the frequency $2 f_{1}-f_{2}$ were recorded in response to two primary tones, $\mathrm{f}_{1}$ and $\mathrm{f}_{2}$, with $\mathrm{f}_{2}$ equal to ABR test frequencies, $\mathrm{f}_{2} / \mathrm{f}_{1}=1.2$, and the $\mathrm{f}_{2}$ level $10 \mathrm{~dB}$ below the $\mathrm{f}_{1}$ level. Primary tone pairs were incremented together in $5 \mathrm{~dB}$ steps from below threshold to $\mathrm{f}_{2}=80 \mathrm{~dB} \mathrm{SPL}$ (for threshold determinations, $\mathrm{f}_{2}$ was kept at $70 \mathrm{~dB}$ and below to avoid system-generated distortion). The DPOAE at $2 \mathrm{f}_{1}-\mathrm{f}_{2}$ was extracted from the averaged spectra, as was the noise floor at points just above and below the $2 \mathrm{f}_{1}-\mathrm{f}_{2}$ frequency. Iso-DPOAE contours were interpolated from the measured growth functions, and threshold was defined as the primary level $\left(\right.$ of $\mathrm{f}_{2}$ ) required to produce a DPOAE of $-5 \mathrm{~dB}$ SPL.

\section{Histologic preparation and assessment}

Following physiologic testing, anesthetized mice were transcardially perfused with $4 \%$ paraformaldehyde in $0.1 \mathrm{M}$ phosphate buffer. Both cochleae were extracted, and the round and oval windows were opened to 
A

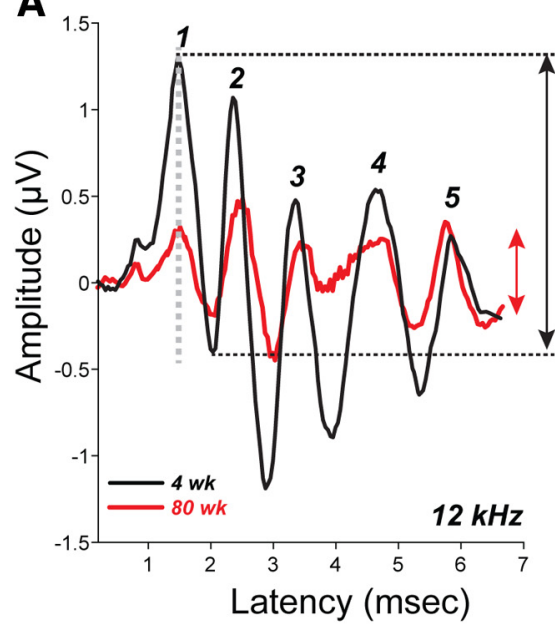

B

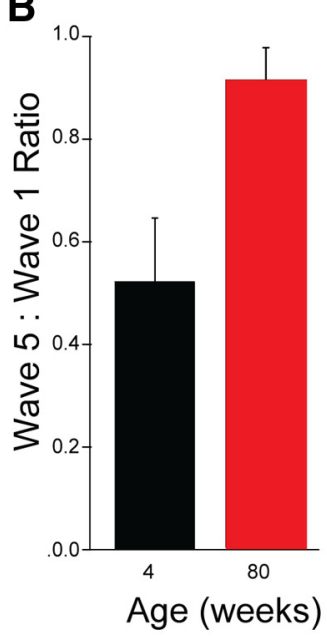

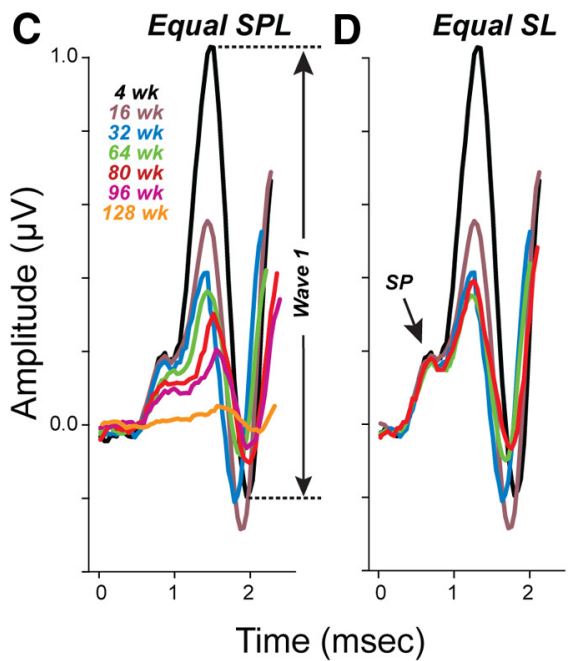

Figure 2. ABR waveforms in aging mice suggest an auditory neuropathy. $A$, Representative ABR waveforms ( $12 \mathrm{kHz}, 80 \mathrm{~dB} \mathrm{SPL})$ at 4 weeks (black) versus 80 weeks (red) show a large reduction in Wave 1 with minimal reduction in Wave 5; dotted lines mark Wave 1 peak and trough. $\boldsymbol{B}$, Mean amplitude ratios for ABR Wave 5 to Wave 1 , at 4 or 80 weeks (12 kHz at $80 \mathrm{~dB}$ SPL)., $\boldsymbol{D}$, Mean waveforms at different ages for the early (cochlear) components of the $A B R(12 \mathrm{kHz})$. In C, responses are shown at equal SPL, i.e., $80 \mathrm{dBSPL}$. Wave 1 peak to trough is indicated for the $4 \mathrm{week}$ response. In D, responses are shown for equal SL, i.e., $50 \mathrm{~dB}$ above ABR threshold. Data are shown for ages to 80 week, the oldest age at which $50 \mathrm{~dB}$ SL data are available. The key in Capplies to all panels; group sizes are as given for Figure 1.

allow intralabyrinthine perfusion of the same fixative. In most cases, one cochlea was processed as an immunostained cochlear whole mount and the other as osmium-stained, plastic-embedded sections as described below. All morphological analyses were performed by an individual having no knowledge of animal age, with subsets double counted by a second individual as a check for consistency.

Cochlear whole mounts. Cochleae were postfixed for $1-2 \mathrm{~h}$ with $4 \%$ paraformaldehyde in $0.1 \mathrm{M}$ phosphate buffer, decalcified for $2-3 \mathrm{~d}$ in $0.12 \mathrm{M}$ EDTA, microdissected into six pieces, and immunostained with antibodies to (1) C-terminal binding protein 2 (mouse anti-CtBP2; BD Biosciences; used at 1:200), (2) myosin-VIIa (rabbit anti-myosin-VIIa; Proteus Biosciences; used at 1:200), and either (3) Na/K-ATPase (goat anti-Na/ K-ATPase; Santa Cruz Biotechnology; used at 1:100), or (4) GluA2 (mouse anti-glutamate receptor 2; Millipore; used at 1:2000) and appropriate secondary antibodies coupled to Alexa Fluors in the red, blue, and green channels.

Cochlear lengths were measured, and a cochlear frequency map computed (Müller et al., 2005), allowing localization of cochlear structures to relevant frequency regions. Confocal $z$-stacks of the $5.6,11.3$, and $32 \mathrm{kHz}$ regions from each ear were obtained (Leica TCS SP2 or SP5) using a high-resolution, oil-immersion objective $((100 \times$, numerical aperture 1.4) with $2 \times$ digital zoom, SP2; or $(63 \times$, numerical aperture 1.3$)$ with $3.17 \times$ digital zoom, SP5). Each stack spanned $78 \mu \mathrm{m}$ of cochlear length, and two adjacent stacks were imaged at each locus in each ear. Care was taken to span (with a step size of $0.25 \mu \mathrm{m}$ ) the entire vertical extent of the hair cells, from cuticular plate to synaptic pole; each stack contained the entire synaptic pole of $\sim 10$ IHCs as viewed from the endolymphatic surface of the organ of Corti.

Image stacks were ported to image-processing software (Amira; Visage Imaging), where IHCs were counted using the faint staining of their nuclei by the anti-CtBP2 antibodies. To count synaptic ribbons, threedimensional (3D) renderings of each confocal $z$-stack were produced using the "connected components" feature in Amira, and rotated to disambiguate the $x-y$ projection images. We determined whether ribbons were associated with glutamate receptors (GluA2) or afferent terminals $(\mathrm{Na} / \mathrm{K}$-ATPase). This analysis was aided by custom software that computed and displayed the $x-y$ projection of the voxel space within 1 $\mu \mathrm{m}$ of the center of each ribbon, as identified from the Amira analysis (Liberman et al., 2011). Juxtaposed ribbons and receptors or ribbons and terminals could then be viewed (and counted) within the generated array of thumbnails. Outer hair cells (OHCs) were counted from the same epithelial whole mounts under Nomarski optics (Nikon Eclipse E800) using a $40 \times$, numerical aperture 0.95 objective; the viewing field spanned
$78 \mu \mathrm{m}$ of cochlear length, and two adjacent fields were counted for each locus in each ear.

Plastic sections. For quantification of spiral ganglion cells, cochleae were fixed as described above, postfixed in 2\% formaldehyde and $2 \%$ glutaraldehyde in $0.1 \mathrm{~m}$ phosphate buffer, decalcified ( $0.12 \mathrm{M}$ EDTA), rinsed in phosphate buffer, and osmicated (osmium tetroxide). Tissues were then rinsed, dehydrated, and embedded in Epon in a stereotyped orientation. Serial sections $(10 \mu \mathrm{m})$ were cut (parallel to the modiolus) using a Leica RM2255 microtome and mounted in Permount on microscope slides. Cochlear regions of interest $(5.6,11.3$, and $32 \mathrm{kHz})$ were identified based on 3D reconstruction and cochlear mapping (Hirose and Liberman, 2003). Using 100×, 1.3 NA oil-immersion objectives and differential interference contrast (DIC) optics, Rosenthal's canal in each cochlear region was live-imaged with a digital camera interfaced to Neurolucida software (MicroBrightField). A mask corresponding to a rectangle $90 \times 60 \mu \mathrm{m}$ was superimposed on the image, and all ganglion cells with a nucleolus wholly within that area (throughout the entire section thickness) were counted. (The software was used to place a small marker at the $x-y$ position of each nucleolus, while repeatedly rolling the focus to image the entire depth of the section.) To correct for possible variation in section thickness, cell counts were divided by the true thickness of each section, as determined by imaging the top and bottom surface with DIC optics and reading output values of the calibrated $z$-axis sensor.

\section{Results}

Cochlear thresholds and suprathreshold response growth

Cochlear responses were measured in male CBA/CaJ mice at ages ranging from shortly after weaning ( 4 weeks) to the end of their life span (144 weeks). Two minimally invasive tests were used, DPOAEs and ABRs, because this combination allows differential diagnosis of the site(s) of dysfunction (for summary, see Starr et al., 2008). DPOAEs are acoustic signals created and amplified by the cochlear epithelium and measured in the ear canal. They require the biological motors in OHCs (Liberman et al., 2002), which amplify sound-evoked cochlear vibration. They do not require IHCs or auditory nerve fibers (Takeno et al., 1994; Kujawa and Liberman, 2009). ABRs are electric potentials recorded from scalp electrodes, and the first ABR wave represents the summed activity of the auditory nerve fibers contacting IHCs (Buchwald and Huang, 1975). Thus, reductions in ABR Wave 1, in the absence of DPOAE changes, indi- 

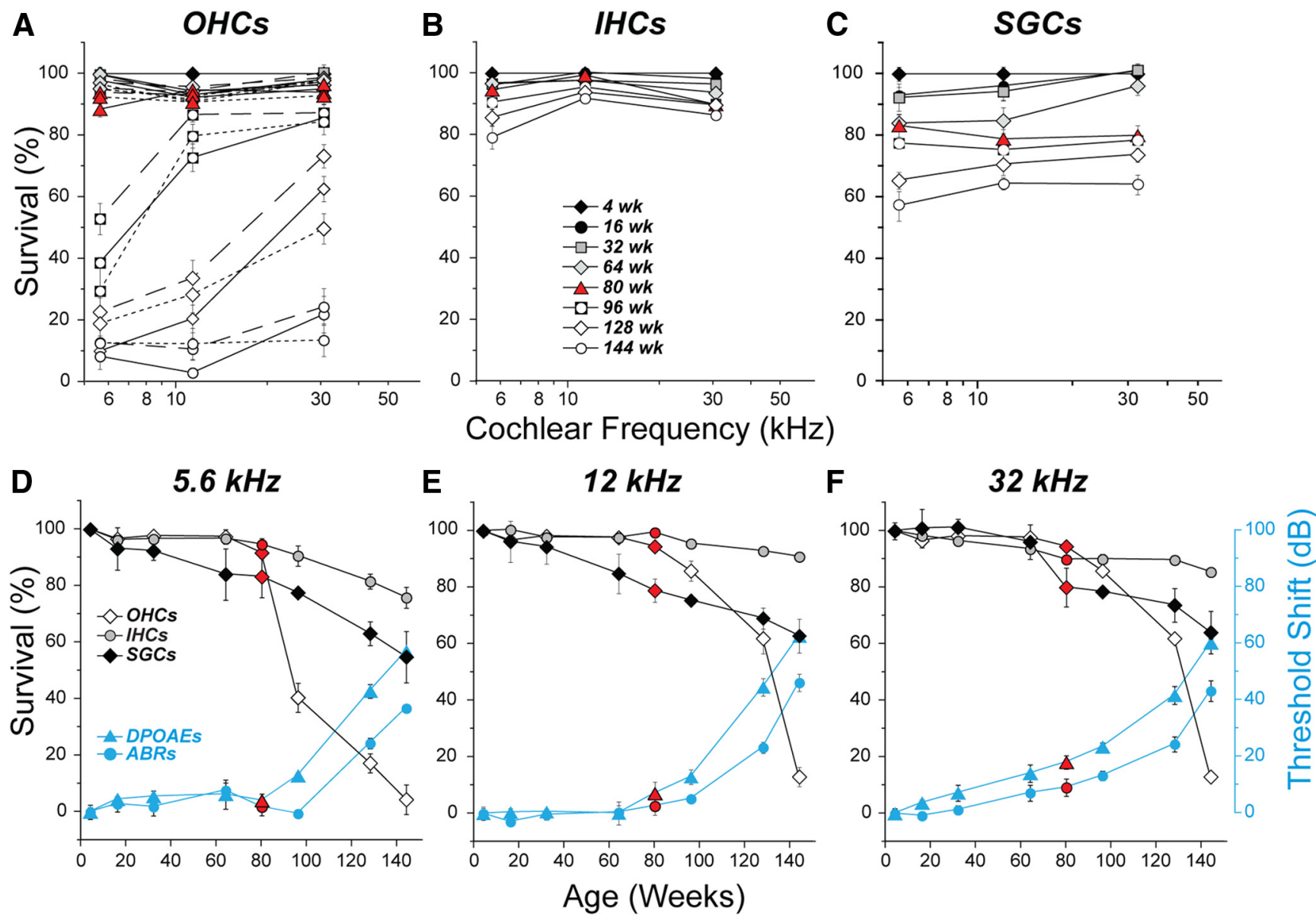

Figure 3. Accelerating threshold deterioration beyond 80 weeks is mirrored by an accelerating loss of $0 \mathrm{HCS}$. $A-C$, Survival of $0 H C s$, IHCs, and spiral ganglion cell (SGCS) at three cochlear locations and eight ages (key in $\boldsymbol{B}$ also apples to $\boldsymbol{A}$ and $\boldsymbol{C}$ ). Data are means ( \pm SEM) expressed as percentage of survival at 4 weeks. Mean 4 week values were as follows: $0 H C s$ (per row), 14.88, 15.57, and 14.64 cells per $100 \mu \mathrm{m}$ of cochlear length; IHCs, 12.99, 13.00, and 12.91 cells per $100 \mu \mathrm{m} ; \mathrm{SGCS}, 8.80,10.60$, and 10.40 cells per $540 \mu \mathrm{m}^{2}$ at 5.6, 11.3, and 32 kHz, respectively. D-F, Mean cell-survival data from panels $\boldsymbol{A}$-C are replotted (left-hand axis) as a function of age at each of the three cochlear locations, where they are compared to mean threshold shifts (4 week means) from the same animals (right-hand axis). Shifts at 144 week are underestimated, since there was no response at the stimulus maximum in some cases. $0 H C$ counts are averages of all three rows. The key in $\boldsymbol{D}$ also applies to $\boldsymbol{E}$ and $\boldsymbol{F}$. Group sizes are as given for Figure 1, except for SGC counts, which were obtained for a subset of ears: 4 weeks (6), 16 weeks (15), 32 weeks (12), 64 weeks (13), 80 weeks (8), 96 weeks (15), 128 weeks (9), and 144 weeks (8).

cate dysfunction in IHCs, auditory nerve fibers, or the synaptic transmission between them.

As shown in Figure 1, $A$ and $B$, age-related threshold elevations in both DPOAEs and ABRs were gradual and mild, and were restricted primarily to middle and high frequencies, out to 96 weeks. Beyond this age, threshold losses grew more rapidly and spread to include all frequencies for both metrics. By 144 weeks, DPOAE and Wave 1 responses were absent at the stimulus maximum for many animals. Similarities in the pattern of agerelated threshold elevation between the two metrics suggest that these shifts arise, at least in part, from OHC dysfunction. However, elevations were greater for ABR at all ages, and the disparity grew with increasing age; thus, age-related changes in cochlear neural function may reflect additional involvement of IHCs, auditory neurons, or the synapses between them, i.e., a type of dysfunction not captured by DPOAEs. Sizable age-related decreases in suprathreshold response amplitudes appeared in the ABR responses at a much earlier age $(\sim 64$ weeks $)$ than in the DPOAE responses $(\sim 128$ weeks), as shown in Figure $1, C$ and $D$, further suggestive of agerelated changes in cochlear neural function. Data in Figure 1, $C$ and $D$, are for stimuli at $12 \mathrm{kHz}$, but similar trends held at all test frequencies from 5.6 to $45.2 \mathrm{kHz}$ (data not shown).
The ABR waveform (Fig. 2A) comprises a series of peaks and troughs within the first $\sim 6 \mathrm{~ms}$ after stimulus onset. The first ABR wave (Wave 1) represents summed activity of the cochlear nerve (Z. Chen et al., 2006). Generators of later waves are less well studied in mouse than in human or cat (Melcher and Kiang, 1996). Here, we designate them as Waves 2-5 to differentiate them from Waves II-V, as defined in larger mammals. Comparison of waveforms in young ( 4 week) versus older ( 80 week) mice reveal that age-related reductions in Wave 1 are more dramatic than those in the later waves (Figs. $2 A, B$ ), which arise from higher centers in the auditory brainstem and midbrain. The Wave 5 peak, which (in cat) is dominated by contributions of the inferior colliculus (Melcher and Kiang, 1996), is particularly robust in the older animals.

To separate the contribution of presynaptic versus postsynaptic dysfunction in the IHC area to the observed age-related deficits in cochlear neural output, we use the summating potential (SP; Figs. 2C,D), which appears as a shoulder on the leading edge of the Wave 1 peak and is dominated by contributions from the IHC receptor potentials (Durrant et al., 1998; Santarelli et al., 2009). Superimposing ABR responses to $80 \mathrm{~dB}$ SPL tones (Fig. $2 C$ ) shows that both the SP and Wave 1 are declining with age. 
However, if we compensate for the agerelated threshold elevation (presumably arising from $\mathrm{OHC}$ dysfunction) by superimposing curves obtained at the same "sensation level" (SL), i.e., decibels re: ABR Wave 1 threshold, we see large decrements in Wave 1 amplitude ( $\sim 65 \%$ at 80 week) with $<5 \%$ decrement in SP amplitude at the same age (Fig. 2D). Such a pattern strongly suggests that the agerelated deficits in ABR responses are dominated by cochlear synaptopathy or neuropathy rather than by defects in mechanoelectric transduction by the hair cells.

\section{Cochlear histopathology}

After final physiological testing, cochleas were processed as immunostained whole mounts or osmium-stained, plasticembedded sections to quantify hair cells, spiral ganglion cells, and synaptic structures, i.e., presynaptic ribbons, postsynaptic glutamate receptors, and cochlearnerve terminal boutons under IHCs.

Hair cells and spiral ganglion cells A normal cochlear epithelium has one row of IHCs and three rows of OHCs, and, in most types of sensorineural hearing loss, OHCs are more vulnerable to damage and cell death than IHCs. In the present study, $\mathrm{OHC}$ loss was minimal until after 80 weeks (Fig. $3 A$ ), after which there was a precipitous decline in survival, appearing first in apical, low-frequency cochlear regions, but gradually reaching the basal high-frequency regions, consistent with a previous report (Spongr et al., 1997). Unlike the special vulnerability of first-row OHCs after acoustic injury (Wang et al., 2002), age-related OHC losses were similar in all three $\mathrm{OHC}$ rows (Fig. $3 A$ ). Inner hair cell losses were minimal in aging ears: survival exceeded $\sim 80 \%$ in all cochlear regions, even at the end of the life span (Fig. 3B). Loss of spiral ganglion cells, the cell bodies of auditory nerve fibers, was slowly progressive throughout the life span and relatively uniform along the cochlear spiral (Fig. 3C). At all ages, fractional ganglion cell losses exceeded those of IHCs, suggesting that ganglion cell degeneration is largely "primary" in nature, rather than "secondary" to loss of their peripheral targets. Losses were $\sim 40 \%$ for the oldest group. A comparison between the age-related progression of cochlear histopathology and cochlear thresholds (Fig. $3 D-F$ ) suggests that $\mathrm{OHC}$ loss is a major contributor to agerelated threshold shifts. For both metrics, changes are slow until 80 weeks of age, beyond which time point the loss/dysfunction accelerates markedly. Furthermore, the end point correlation, i.e., virtually complete $\mathrm{OHC}$ loss associated with a $\sim 50 \mathrm{~dB}$ threshold elevation, fits well with previous work on structure function correlations after drug- or noise-induced $\mathrm{OHC}$ loss (Dallos and Harris, 1978; Liberman et al., 2002).

\section{Synapses between hair cells and spiral ganglion neurons}

Spiral ganglion cells fall into two distinct types: a majority population (95\%) of large myelinated bipolar neurons with peripheral axons that target exclusively the IHCs and a minority population (5\%) of small unmyelinated neurons with peripheral axons that contact exclusively OHCs (Spoendlin, 1972). Thus, we concentrated on the synaptic connections in the IHC area. To quantify the synapses and synaptic terminals, we immunostained cochlear epithelial whole mounts with antibodies to (1) a prominent component of the presynaptic ribbon (CtBP2; Khimich et al., 2005), which clearly stains ribbons at both IHCs and OHCs, (2) an AMPA-type glutamate receptor prominently expressed in the postsynaptic density within the auditory-nerve terminal boutons at IHCs (GluA2; Matsubara et al., 1996) or an antibody to an isoform of $\mathrm{Na} / \mathrm{K}$-ATPase (NKA $\alpha 3$ ) to stain unmyelinated terminals of cochlear nerve fibers contacting IHCs (McLean et al., 2009), and (3) an unconventional myosin, myosin VIIa, expressed in IHC and OHC cytoplasm.

As shown in Figure $4 B$, this triple immunostaining, in a normal young ear, reveals closely juxtaposed pairs of ribbons and glutamate receptor patches studding the basolateral membrane of the IHCs, with 15-20 pairs per IHC in the middle cochlear regions (Kujawa and Liberman 2009). These synaptic counts fit well with observations from serial-section ultrastructural studies of the mouse IHC area (Stamataki et al., 2006). As schematized in Figure $4 A$, such electron microscopic studies also show that each auditory nerve fiber makes synaptic contact with a single IHC via a single terminal bouton, with a single postsynaptic density that is 


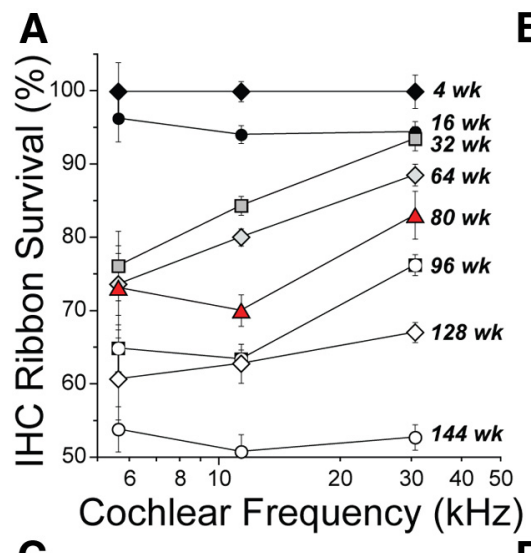

C
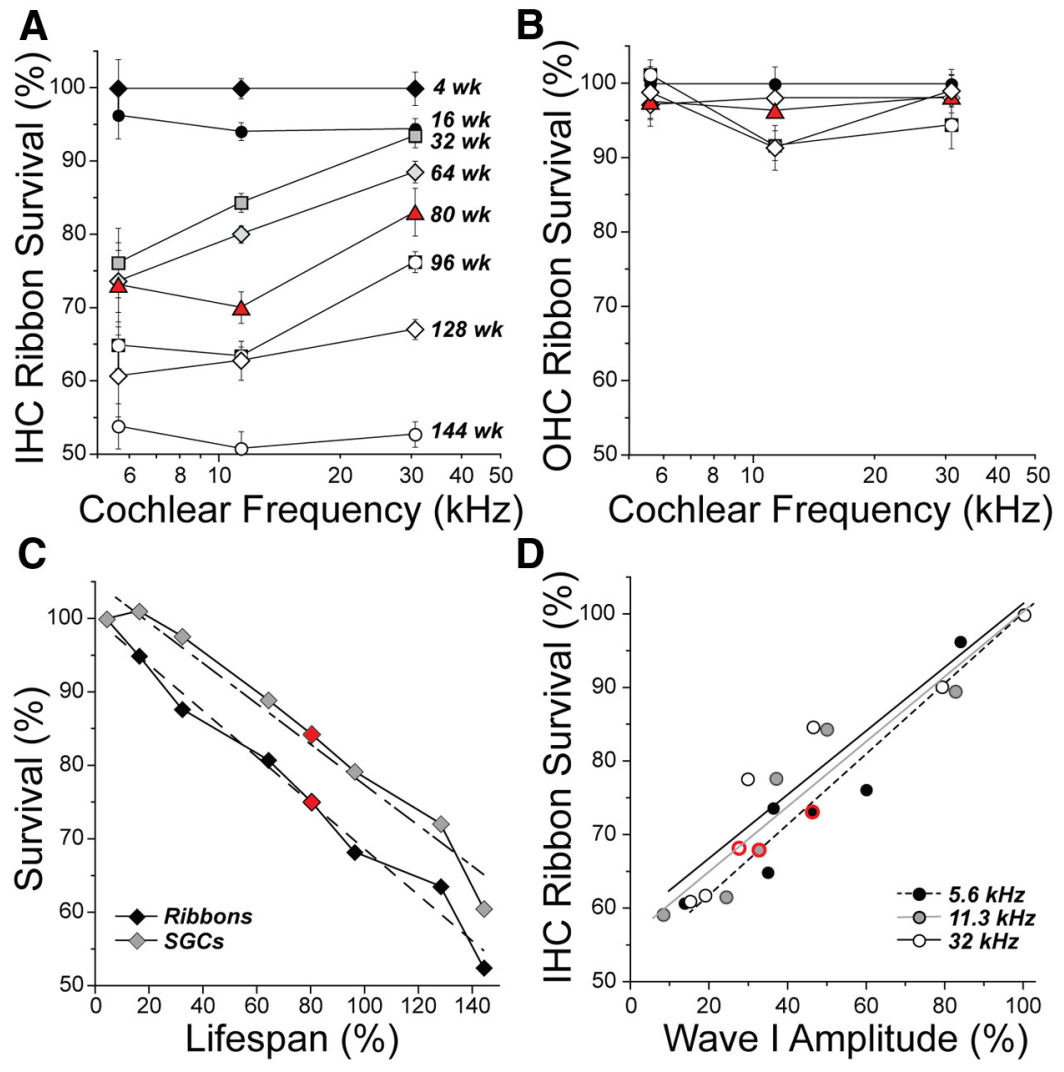

Figure 5. Synaptic counts in IHCs, but not $\mathrm{OHCS}$, decrease steadily throughout the cochlea from 4 to 144 weeks. $A, B$, Counts of presynaptic ribbons in $\mathrm{IHCS}(\boldsymbol{A})$ and $\mathrm{OHCs}(\boldsymbol{B})$ at three cochlear locations versus age. Means ( \pm SEMs) are normalized to 4 week values: $2.45,2.52$, and 2.19 ribbons per $\mathrm{OHC}$ and 9.25, 17.91, and 17.11 ribbons per $\mathrm{IHC}$ at 5.6, 11.3 , and $32 \mathrm{kHz}$, respectively. $\boldsymbol{C}$, IHC ribbon counts from $\boldsymbol{A}$ were averaged across cochlear frequency, replotted versus life span, and compared to frequency-averaged spiral ganglion cell (SGC) counts from the same animals. $\boldsymbol{D}$, IHC ribbon counts from $\boldsymbol{A}$ are plotted versus mean Wave 1 amplitudes (at $80 \mathrm{~dB} \mathrm{SPL}$ ) from the same animals (except the 144 week group, where ABR waveforms were so abnormal that wave classification was unreliable). Red-circled points are those from the 80 week group. Best-fit lines are shown for each stimulus/cochlear frequency. Group sizes are as given for Figures 1 and 3.

associated with a single presynaptic ribbon (Liberman, 1980; Liberman et al., 1990). Thus, synaptic counts based on confocal projections such as those in Figure 4 provide an estimate of the maximum number of auditory nerve fibers that could be carrying information from the cochlea to the brain. High-power examination of all the synaptic elements, as illustrated by a small subset in Figure $4 D$, revealed that, in the youngest ears, $>95 \%$ of all presynaptic ribbons from all cochlear regions examined were immediately juxtaposed to a glutamate receptor patch or a cochlear nerve terminal (data not shown), and correspondingly, orphan ribbons, such as the one shown by the arrow in Figure $4 D$ were quite rare.

In older ears, as shown in Figure $4 C$, the number of paired synaptic puncta was reduced. Counts of IHC ribbons in all of the age groups (Fig. 5A) show a steady decline in all three cochlear regions evaluated. Losses were initially greater in the apex, but with increasing age, the synaptopathy spread throughout the cochlear spiral. In contrast, $\mathrm{OHC}$ ribbons were well preserved in the aging ear: for those $\mathrm{OHCs}$ remaining, ribbon losses were $<10 \%$ at all cochlear frequencies sampled, to 128 weeks (Fig. $5 B$ ). When plotted versus age (Fig. 5C), IHC synaptic decline begins at weaning and progresses steadily until death. Loss of the neuronal cell bodies of the fibers contacting the IHCs, also plotted in Figure $5 C$, shows a similarly steady progression, but after a delay of a few months. High-power examination (Fig. 4D) showed that, even for the oldest age group, the number of orphan ribbons was still very small $(<5 \%$ at the 12 and $32 \mathrm{kHz}$ regions, and $<10 \%$ at the $5.6 \mathrm{kHz}$ region). Thus, IHC ribbon counts are an excellent proxy for synaptic counts, and, therefore also for an estimate of the numbers of auditory nerve fibers remaining.

ABR Wave 1 amplitudes provide information about the functional integrity of these auditory nerve fibers. In a previous study of noise-induced cochlear neurodegeneration, Wave 1 amplitudes declined in proportion to ribbon loss after cochlear thresholds had recovered to preexposure values (Kujawa and Liberman, 2009). In the present study, synapse survival and normalized Wave 1 amplitude also are highly correlated across all ages and all frequencies studied (Fig. 5D).

\section{Discussion}

\section{Threshold shifts and hair cell loss}

In humans, threshold sensitivity declines with age, with the pace of deterioration worse in males than females, and worse at high frequencies than low (for review, see Goŕdon-Salant 2005). Age-related threshold shifts are remarkably similar in male humans and male CBA/CaJ mice, as shown in Figure 6, where human data are taken from otologically normal males with no stated history or audiometric evidence of noise exposure (Pearson et al., 1995). To make the comparison, we normalized age to mean life span and adjusted for differences in frequency range (mice are high-frequency mammals), using cochlear maps to identify frequencies representing the same relative positions along the mechanically tuned cochlear spiral. At both basal (35\% locus) and apical (70\%) cochlear locations, in both mouse and man, the rate of threshold deterioration increases dramatically at ages beyond $\sim 80 \%$ of mean life span. Such data provide an estimate of the threshold declines attributable to aging per se in the human, as the mice received only low- to moderate-level sound exposures over the course of their entire life spans.

Although threshold deterioration in CBA/CaJ closely mirrors that in average human data, for any individual, genetic and environmental factors, e.g., noise exposure, can shape the nature and degree of age-related hearing loss. Certain other inbred strains of mice show a more rapid decline in cochlear function as they age (Zheng et al., 1999). The C57BL/6 strain, for example, has received extensive study as a model of age-related hearing loss. Threshold elevation in this strain is associated with a splice variant of the gene for cadherin 23 (Noben-Trauth et al., 2003), a component of the stereocilia tip links necessary for hair cell mechanotransduction (Siemens et al., 2004). The early appearance and accelerated rate of threshold elevation (Fig. 6A) and neural loss (Fig. 6B) suggests that the cochlear anomaly in this strain may be relevant to only a subset of aging human ears.

The age-related loss of OHCs observed here is quantitatively consistent with previous studies in CBA inbred mice (Spongr et 
al., 1997; Ohlemiller et al., 2010; CBA/CaJ, $\mathrm{CBA} / \mathrm{J}$ ) and may account for much of the age-related threshold elevation in our mouse model (Fig. 3D-F). Loss of OHCs (Dallos and Harris, 1978) or the prestinbased molecular motor that drives the OHC-based "cochlear amplifier" (Liberman et al., 2002) leads to $\sim 50 \mathrm{~dB}$ of threshold elevation; correspondingly, near-total loss of OHCs in our oldest mice (Fig. 3D-F) was associated with an $\sim 50$ $\mathrm{dB}$ threshold shift. Cochlear thresholds can also be elevated by a decrease in endocochlear potential (EP), the $100 \mathrm{mV}$ potential across the sensory epithelium that helps drive hair cell transduction. In gerbil, pathology of the stria vascularis, with associated EP decline, has been described as a primary contributor to age-related threshold elevations (Schmiedt et al., 2002). Although there is an age-related EP decline in CBA/CaJ, it is minimal in males (Ohlemiller et al., 2010), and the data in Figure 4 suggest that it need not be invoked to account for the age-related threshold shifts observed here.
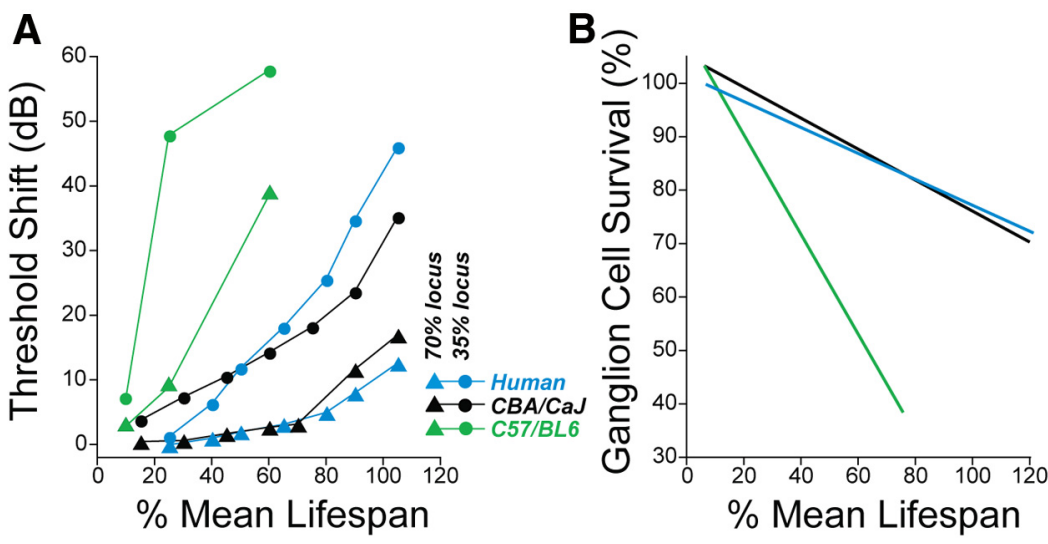

Figure 6. Age-related declines in threshold and ganglion cell survival in mouse and man. A, Age-related threshold shifts versus percentage mean life span at two cochlear regions in humans versus two common strains of laboratory mice. Human audiometric thresholds are values for males from Pearson et al. (1995). ABR thresholds for CBA/CaJ are from the present study; data for (57BL/6 are from Hequembourg and Liberman (2001). To normalize for difference in mean life spans, we used 2.1 years for male CBA/CaJ and C57BL/6 mice (http://research.jax.org/faculty/harrison/ger1vi_LifeStudy1.html) and 76 years for human males (Kochanek et al. 2012). To normalize for difference in frequency range, we matched cochlear location, choosing loci 35 and $70 \%$ of the distance from the base, which, according to the relevant cochlear frequency maps (Schuknecht, 1994; Müller et al., 2005), correspond to 32 and $12 \mathrm{kHz}$ in mice versus 4 and $0.75 \mathrm{kHz}$ in humans. B, Spiral ganglion cell counts for $\mathrm{CBA} / \mathrm{CaJ}$ are from the present study, averaged across all cochlear regions and displayed as the best-fit straight line. Group sizes are as given for Figure 3. Best-fit lines for C57BL/6 and human are computed from data in previous studies (Hequembourg and Liberman, 2001; Makary et al., 2011) and are also collapsed across all cochlear regions. For both panels, when data points represent a range of ages, the midpoint was used.

\section{Cochlear neuropathy and hidden hearing loss}

All acoustic information is carried from the hair cells to the brainstem via the bipolar sensory neurons of the auditory nerve, numbering about 35,000 in human (Spoendlin and Schrott, 1989). Each auditory nerve fiber has a cell body in the spiral ganglion, a peripheral axon directed to the organ of Corti and a central axon to the cochlear nucleus. In the aging mouse, loss of spiral ganglion cells occurs before loss of hair cells (Fig. 3), and the rate of loss is similar in mouse and human, when age is normalized to a percentage of total life span (Fig. 6B). In aging human ears with full complements of hair cells, mean ganglion cell losses reach $\sim 30 \%$ at 95 years (Makary et al., 2011); correspondingly, neuronal losses reached $40 \%$ in old CBA/CaJ mice (144 weeks; Fig. 5B). These spiral ganglion cell losses are remarkably similar to those reported for aging gerbil (Keithley et al., 1989) and rat (Keithley and Feldman, 1979), but can be contrasted with the accelerated neuronal loss in $\mathrm{C} 57 \mathrm{BL} / 6$ mice, which reaches $\sim 30 \%$ by only 30 weeks of age (Hequembourg and Liberman, 2001).

Counts of spiral ganglion cells greatly underestimate the degree of cochlear neuropathy in the aging ear, because the cochlear synapses (and peripheral axons) of spiral ganglion cells degenerate well before their cell bodies (and central axons), as suggested by Figure 5C. Similar conclusions can be drawn from electron microscopic studies on aging C57BL/6 mice, where the progression of degeneration from synaptic terminal to peripheral axon to cell body has been well documented (White et al., 2000; Stamataki et al., 2006). Counts in human temporal bones also show greater age-related loss of peripheral versus central axons of spiral ganglion cells (Felix et al., 1990), and multiple reports show isolated degeneration of cochlear peripheral axons in aging ears with normal hair cell and ganglion cell counts (Nadol, 1979; Spoendlin and Schrott, 1988, 1989; M. A. Chen et al., 2006).

\section{A lifetime of moderate-level sound exposure?}

A similar progression of neurodegeneration has been observed in ears with (Liberman and Kiang, 1978) and without (Kujawa and Liberman 2009) hair cell loss after acoustic overstimulation. When exposures are titrated to produce transient threshold elevation, followed by full recovery of hair cell function, the substantial loss of IHC synapses and auditory nerve peripheral terminals is complete by $1 \mathrm{~d}$ after exposure, whereas the death of spiral ganglion cells continues for $>1$ year (Kujawa and Liberman, 2009). The neuropathy may arise from a glutamate excitotoxicity that occurs immediately after acoustic overstimulation (Puel et al., 1998) or ischemia (Pujol et al., 1990; Puel et al., 1994), or which may accumulate over the course of a lifetime of more moderate-level sound exposures (Maison et al., 2013). The relative selectivity of IHC ribbon loss with age observed here (Fig. 5) is consistent with such an hypothesis, as $\mathrm{OHC}$ synaptic terminals do not express the same AMPA-type glutamate receptors as IHC synaptic terminals (Liberman et al., 2011) and do not degenerate when the cochlea is perfused with kainate, as IHC terminals do (Pujol et al. 1985; Juiz et al. 1989).

Neurophysiological study (Furman et al., 2013) suggests that noise-induced neuropathy is selective for the subset of auditory nerve fibers, comprising $\sim 40 \%$ of the population, with high thresholds and low spontaneous rates (SRs). A single-fiber study of auditory-nerve response in aging gerbils also reported a decline in the proportion of low-SR fibers (Schmiedt et al., 1996), and a morphological study in aging C57BL/6 mice reported preferential loss of small afferent terminals on IHCs (Stamataki et al., 2006), which correspond to fibers with low SR (Liberman, 1982). Selective low-SR neuropathy in our aging mice would explain why a substantial loss of IHC-afferent fiber synapses (Fig. $5 A$ ) has minimal effect on ABR thresholds (Fig. $3 D-F$ ), but is proportionately reflected in suprathreshold ABR amplitudes (Fig. 5D).

The close correspondence between synaptic survival and ABR Wave 1 amplitude, which reflects summed activity of auditory 
nerve fibers (Fig. 5D), suggests that this non-invasive auditory test could be useful in diagnosing cochlear synaptopathy in humans, at least among those with near-normal threshold audiograms. Indeed, in humans with good audiometric thresholds, Wave I was $\sim 78 \%$ smaller among males over 70 compared to those under 40 years (Konrad-Martin et al., 2012), whereas Wave $\mathrm{V}$, reflecting contributions of auditory midbrain nuclei, was reduced by only $22 \%$. This relative enhancement in Wave V/Wave 1 ratio is similar to that observed in our aging mice (Fig. 2). It may reflect an increase in "central gain" after partial peripheral deafferentation (Schaette and McAlpine, 2011) and has been implicated in the generation of tinnitus, a common affliction in aging (Lockwood et al., 2002).

\section{Functional implications}

Age-related damage to hair cells elevates auditory thresholds, and when this occurs in important speech frequency regions, conversation-level speech $(\sim 60 \mathrm{~dB}$ SPL) does not provide sufficient information: speech may be heard, but not understood. Reduced audibility, however, cannot fully account for the poorer performance of aging listeners in adverse listening situations, where speech signals must be extracted from backgrounds of noise or reverberation. This poorer performance of older listeners on a variety of suprathreshold speech and temporal processing tasks can already be seen in middle age (Abel et al., 1990; Grose et al. 2006; Grose and Mamo 2010), and indeed may be progressive throughout the adult life span (Snell and Frisina, 2000). Such findings parallel the common experience of poorer hearing in noise that occurs well before age-related threshold elevation (Ruggles et al., 2012).

Declining auditory performance in aging listeners with normal audiometric thresholds is often attributed to changes in central circuits, because the view that normal threshold indicates a lack of cochlear involvement is pervasive (Humes et al., 2012). Here, we show that dramatic cochlear synaptopathy precedes age-related hair cell damage and/or threshold elevation. This synaptopathy progresses throughout the life span, and is likely selective for auditory-nerve fibers with low SR (Schmiedt et al. 1996; Furman et al. 2013). Since low-SR fibers have higher thresholds and wider dynamic ranges than their high-SR counterparts (Winter et al. 1990), they are also more resistant to masking in the presence of continuous broadband noise (Costalupes et al. 1984). Thus, an age-related loss of low-SR fibers may be an important contributor to declining auditory performance in aging listeners, particularly with respect to speech-in-noise difficulties. Present results underscore the importance of understanding peripheral status when studying central contributions to auditory aging. Translation to clinical diagnosis will require noninvasive tools. Fortunately, key functional clues to this synaptopathy are available in the ABR response; these could be optimized and accessed noninvasively, enhancing the possibilities for translation to human clinical characterization.

\section{References}

Abel SM, Krever EM, Alberti PW (1990) Auditory detection, discrimination and speech processing in ageing, noise sensitive and hearing-impaired listeners. Scand Audiol 19:43-54. CrossRef Medline

Buchwald JS, Huang C (1975) Far-field acoustic response: origins in the cat. Science 189:382-384. CrossRef Medline

Chen MA, Webster P, Yang E, Linthicum FH Jr (2006) Presbycusic neuritic degeneration within the osseous spiral lamina. Otol Neurotol 27:316322. CrossRef Medline

Chen Z, Mikulec AA, McKenna MJ, Sewell WF, Kujawa SG (2006) A method for intracochlear drug delivery in the mouse. J Neurosci Methods 150:67-73. CrossRef Medline
Costalupes JA, Young ED, Gibson DJ (1984) Effects of continuous noise backgrounds on rate response of auditory nerve fibers in cat. J Neurophysiol 51:1326-1344. Medline

Dallos P, Harris D (1978) Properties of auditory nerve responses in absence of outer hair cells. J Neurophysiol 41:365-383. Medline

Dubno JR, Dirks DD, Morgan DE (1984) Effects of age and mild hearing loss on speech recognition in noise. J Acoust Soc Am 76:87-96. CrossRef Medline

Durrant JD, Wang J, Ding DL, Salvi RJ (1998) Are inner or outer hair cells the source of summating potentials recorded from the round window? J Acoust Soc Am 104:370-377. CrossRef Medline

Felix H, Johnsson LG, Gleeson M, Pollak A (1990) Quantitative analysis of cochlear sensory cells and neuronal elements in man. Acta Otolaryngol Suppl 470:71-79. Medline

Frisina DR, Frisina RD (1997) Speech recognition in noise and presbycusis: relations to possible neural mechanisms. Hear Res 106:95-104. CrossRef Medline

Furman AC, Kujawa SG, Liberman MC (2013) Noise-induced cochlear neuropathy is selective for fibers with low spontaneous rates. J Neurophysiol. Advance online publication. Retrieved April 30, 2013. doi: 10.1152/jn.00164.2013. CrossRef Medline

Goŕdon-Salant S (2005) Hearing loss and aging: new research findings and clinical implications. J Rehabil Res Dev 42 [Suppl 2]:9-24. Medline

Goŕdon-Salant S, Fitzgibbons PJ (1993) Temporal factors and speech recognition performance in young and elderly listeners. J Speech Hear Res 36:1276-1285. Medline

Grose JH, Mamo SK (2010) Processing of temporal fine structure as a function of age. Ear Hear 31:755-760. CrossRef Medline

Grose JH, Hall JW 3rd, Buss E (2006) Temporal processing deficits in the pre-senescent auditory system. J Acoust Soc Am 119:2305-2315. CrossRef Medline

Guimaraes P, Zhu X, Cannon T, Kim S, Frisina RD (2004) Sex differences in distortion product otoacoustic emissions as a function of age in CBA mice. Hear Res 192:83-89. CrossRef Medline

Henry KR (2004) Males lose hearing earlier in mouse models of late-onset age-related hearing loss; females lose hearing earlier in mouse models of early-onset hearing loss. Hear Res 190:141-148. CrossRef Medline

Hequembourg S, Liberman MC (2001) Spiral ligament pathology: a major aspect of age-related cochlear degeneration in C57BL/6 mice. J Assoc Res Otolaryngol 2:118-129. Medline

Hirose K, Liberman MC (2003) Lateral wall histopathology and endocochlear potential in the noise-damaged mouse cochlea. J Assoc Res Otolaryngol 4:339-352. CrossRef Medline

Humes LE, Dubno JR, Goŕdon-Salant S, Lister JJ, Cacace AT, Cruickshanks KJ, Gates GA, Wilson RH, Wingfield A (2012) Central presbycusis: A review and evaluation of the evidence. J Am Acad Audiol 23:635-666. CrossRef Medline

Juiz JM, Rueda J, Merchán JA, Sala ML (1989) The effects of kainic acid on the cochlear ganglion of the rat. Hear Res 40:65-74. CrossRef Medline

Keithley EM, Feldman ML (1979) Spiral ganglion cell counts in an agegraded series of rat cochleas. J Comp Neurol 188:429-442. CrossRef Medline

Keithley EM, Ryan AF, Woolf NK (1989) Spiral ganglion cell density in young and old gerbils. Hear Res 38:125-133. CrossRef Medline

Khimich D, Nouvian R, Pujol R, Tom Dieck S, Egner A, Gundelfinger ED, Moser T (2005) Hair cell synaptic ribbons are essential for synchronous auditory signalling. Nature 434:889-894. CrossRef Medline

Kochanek KD, Xu J, Murphy SL, Miniño A, Kung H-C (2012) Deaths: final data for 2009. In: National vital statistics reports, Vol 60, No 3. Hyattsville, MD: National Center for Health Statistics.

Konrad-Martin D, Dille MF, McMillan G, Griest S, McDermott D, Fausti SA, Austin DF (2012) Age-related changes in the auditory brainstem response. J Am Acad Audiol 23:18-35. Medline

Krull V, Humes LE, Kidd GR (2013) Reconstructing wholes from parts: Effects of modality, age, and hearing loss on word recognition. Ear Hear 34:e14-e23. Medline

Kujawa SG, Liberman MC (2009) Adding insult to injury: cochlear nerve degeneration after "temporary" noise-induced hearing loss. J Neurosci 29:14077-14085. CrossRef Medline

Liberman LD, Wang H, Liberman MC (2011) Opposing gradients of ribbon size and AMPA receptor expression underlie sensitivity differences 
among cochlear-nerve/hair-cell synapses. J Neurosci 31:801-808. CrossRef Medline

Liberman MC (1980) Morphological differences among radial afferent fibers in the cat cochlea: an electron-microscopic study of serial sections. Hear Res 3:45-63. CrossRef Medline

Liberman MC (1982) Single-neuron labeling in the cat auditory nerve. Science 216:1239-1241. CrossRef Medline

Liberman MC, Kiang NY (1978) Acoustic trauma in cats. Cochlear pathology and auditory-nerve activity. Acta Otolaryngol Suppl 358:1-63. Medline

Liberman MC, Dodds LW, Pierce S (1990) Afferent and efferent innervation of the cat cochlea: quantitative analysis with light and electron microscopy. J Comp Neurol 301:443-460. CrossRef Medline

Liberman MC, Gao J, He DZ, Wu X, Jia S, Zuo J (2002) Prestin is required for electromotility of the outer hair cell and for the cochlear amplifier. Nature 419:300-304. CrossRef Medline

Lockwood AH, Salvi RJ, Burkard RF (2002) Tinnitus. N Engl J Med 347: 904-910. CrossRef Medline

Maison SF, Usubuchi H, Liberman MC (2013) Efferent feedback minimizes cochlear neuropathy from moderate noise exposure. J Neurosci 33:55425552. CrossRef Medline

Makary CA, Shin J, Kujawa SG, Liberman MC, Merchant SN (2011) Agerelated primary cochlear neuronal degeneration in human temporal bones. J Assoc Res Otolaryngol 12:711-717. CrossRef Medline

Matsubara A, Laake JH, Davanger S, Usami S, Ottersen OP (1996) Organization of AMPA receptor subunits at a glutamate synapse: a quantitative immunogold analysis of hair cell synapses in the rat organ of Corti. J Neurosci 16:4457-4467. Medline

McLean WJ, Smith KA, Glowatzki E, Pyott SJ (2009) Distribution of the $\mathrm{Na}, \mathrm{K}-\mathrm{ATPa}$ a alpha subunit in the rat spiral ganglion and organ of corti. J Assoc Res Otolaryngol 10:37-49. CrossRef Medline

Melcher JR, Kiang NY (1996) Generators of the brainstem auditory evoked potential in cat. III: Identified cell populations. Hear Res 93:52-71. CrossRef Medline

Müller M, von HünerbeinK, Hoidis S, Smolders JW (2005) A physiological place-frequency map of the cochlea in the CBA/J mouse. Hear Res 202: 63-73. CrossRef Medline

Nadol JB Jr (1979) Electron microscopic findings in presbycusic degeneration of the basal turn of the human cochlea. Otolaryngol Head Neck Surg 87:818-836. Medline

Noben-Trauth K, Zheng QY, Johnson KR (2003) Association of cadherin 23 with polygenic inheritance and genetic modification of sensorineural hearing loss. Nat Genet 35:21-23. CrossRef Medline

Ohlemiller KK, Dahl AR, Gagnon PM (2010) Divergent aging characteristics in $\mathrm{CBA} / \mathrm{J}$ and $\mathrm{CBA} / \mathrm{CaJ}$ mouse cochleae. J Assoc Res Otolaryngol 11:605-623. CrossRef Medline

Pearson JD, Morrell CH, Goŕdon-Salant S, Brant LJ, Metter EJ, Klein LL, Fozard JL (1995) Gender differences in a longitudinal study of ageassociated hearing loss. J Acoust Soc Am 97:1196-1205. CrossRef Medline

Puel JL, Pujol R, Tribillac F, Ladrech S, Eybalin M (1994) Excitatory amino acid antagonists protect cochlear auditory neurons from excitotoxicity. J Comp Neurol 341:241-256. CrossRef Medline

Puel JL, Ruel J, Gervais d'Aldin C, Pujol R (1998) Excitotoxicity and repair of cochlear synapses after noise-trauma induced hearing loss. Neuroreport 9:2109-2114. CrossRef Medline

Pujol R, Lenoir M, Robertson D, Eybalin M, Johnstone BM (1985) Kainic acid selectively alters auditory dendrites connected with inner hair cells. Hear Res 18:145-151. CrossRef Medline

Pujol R, Rebillard G, Puel JL, Lenoir M, Eybalin M, Recasens M (1990) Glutamate neurotoxicity in the cochlea: a possible consequence of ischaemic or anoxic conditions occurring in ageing. Acta Otolaryngol Suppl 476:32-36. Medline

Ruggles D, Bharadwaj H, Shinn-Cunningham BG (2012) Why middle- aged listeners have trouble hearing in everyday settings. Curr Biol 22:1417-1422. CrossRef Medline

Santarelli R, Del Castillo I, Rodríguez-BallesterosM, Scimemi P, Cama E, Arslan E, Starr A (2009) Abnormal cochlear potentials from deaf patients with mutations in the otoferlin gene. J Assoc Res Otolaryngol 10: 545-556. CrossRef Medline

Schaette R, McAlpine D (2011) Tinnitus with a normal audiogram: physiological evidence for hidden hearing loss and computational model. J Neurosci 31:13452-13457. CrossRef Medline

Schmiedt RA, Mills JH, Boettcher FA (1996) Age-related loss of activity of auditory-nerve fibers. J Neurophysiol 76:2799-2803. Medline

Schmiedt RA, Okamura HO, Lang H, Schulte BA (2002) Ouabain application to the round window of the gerbil cochlea: a model of auditory neuropathy and apoptosis. J Assoc Res Otolaryngol 3:223-233. CrossRef Medline

Schuknecht HF (1994) Auditory and cytocochlear correlates of inner ear disorders. Otolaryngol Head Neck Surg 110:530-538. Medline

Schuknecht HF, Woellner RC (1953) Hearing losses following partial section of the cochlear nerve. Laryngoscope 63:441-465. Medline

Siemens J, Lillo C, Dumont RA, Reynolds A, Williams DS, Gillespie PG, Müller U (2004) Cadherin 23 is a component of the tip link in hair-cell stereocilia. Nature 428:950-955. CrossRef Medline

Snell KB, Frisina DR (2000) Relationships among age-related differences in gap detection and word recognition. J Acoust Soc Am 107:1615-1626. CrossRef Medline

Spoendlin H (1972) Innervation densities of the cochlea. Acta Otolaryngol 73:235-248. CrossRef Medline

Spoendlin H, Schrott A (1988) The spiral ganglion and the innervation of the human organ of Corti. Acta Otolaryngol (Stockh) 105:403-410. CrossRef

Spoendlin H, Schrott A (1989) Analysis of the human auditory nerve. Hear Res 43:25-38. CrossRef Medline

Spongr VP, Flood DG, Frisina RD, Salvi RJ (1997) Quantitative measures of hair cell loss in CBA and C57BL/6 mice throughout their life spans. J Acoust Soc Am 101:3546-3553. CrossRef Medline

Stamataki S, Francis HW, Lehar M, May BJ, Ryugo DK (2006) Synaptic alterations at inner hair cells precede spiral ganglion cell loss in aging C57BL/6J mice. Hear Res 221:104-118. CrossRef Medline

Starr A, Zeng FG, Michalewski HJ, Moser T (2008) Perspectives on auditory neuropathy: disorders of inner hair cell, auditory nerve, and their synapse. In: The senses: a comprehensive reference (Basbaum AI, Kaneko A, Shepherd GM, Westheimer G, eds), Vol 3, Audition (Dallos P, Oertel D, eds), pp 397-412. San Diego: Academic.

Takeno S, Harrison RV, Ibrahim D, Wake M, Mount RJ (1994) Cochlear function after selective inner hair cell degeneration induced by carboplatin. Hear Res 75:93-102. CrossRef Medline

Walton JP (2010) Timing is everything: Temporal processing deficits in the aged auditory brainstem. Hear Res 264:63-69. CrossRef Medline

Wang Y, Hirose K, Liberman MC (2002) Dynamics of noise-induced cellular injury and repair in the mouse cochlea. J Assoc Res Otolaryngol 3:248 268. CrossRef Medline

White JA, Burgess BJ, Hall RD, Nadol JB (2000) Pattern of degeneration of the spiral ganglion cell and its processes in the C57BL/6J mouse. Hear Res 141:12-18. CrossRef Medline

Winter IM, Robertson D, Yates GK (1990) Diversity of characteristic frequency rate-intensity functions in guinea pig auditory nerve fibres. Hear Res 45:191-202. CrossRef Medline

Working Group on Speech Understanding, Committee on Hearing, Bioacoustics, and Biomechanics (1988) Speech understanding and aging. J Acoust Soc Am 83:859-895. CrossRef Medline

Zheng QY, Johnson KR, Erway LC (1999) Assessment of hearing in 80 inbred strains of mice by ABR threshold analyses. Hear Res 130:94-107. CrossRef Medline 